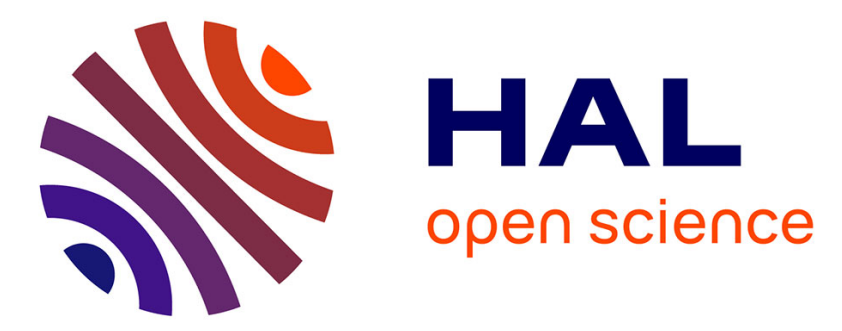

\title{
Complementary description of Neoseiulus tunus (De Leon) (Acari: Mesostigmata: Phytoseiidae) and observation on its reproductive strategy
}

Ana C.C. Cavalcante, Peterson R Demite, Felipe S.R. Amaral, Antonio C. Lofego, Gilberto J. de Moraes

\section{To cite this version:}

Ana C.C. Cavalcante, Peterson R Demite, Felipe S.R. Amaral, Antonio C. Lofego, Gilberto J. de Moraes. Complementary description of Neoseiulus tunus (De Leon) (Acari: Mesostigmata: Phytoseiidae) and observation on its reproductive strategy. Acarologia, 2017, 57 (3), pp.591-599. 10.24349/acarologia/20174178 . hal-01535763

\section{HAL Id: hal-01535763 https://hal.science/hal-01535763}

Submitted on 9 Jun 2017

HAL is a multi-disciplinary open access archive for the deposit and dissemination of scientific research documents, whether they are published or not. The documents may come from teaching and research institutions in France or abroad, or from public or private research centers.
L'archive ouverte pluridisciplinaire HAL, est destinée au dépôt et à la diffusion de documents scientifiques de niveau recherche, publiés ou non, émanant des établissements d'enseignement et de recherche français ou étrangers, des laboratoires publics ou privés.

\section{(1) (1) $\$$}

Distributed under a Creative Commons Attribution - NonCommercial - NoDerivatives 44.0 


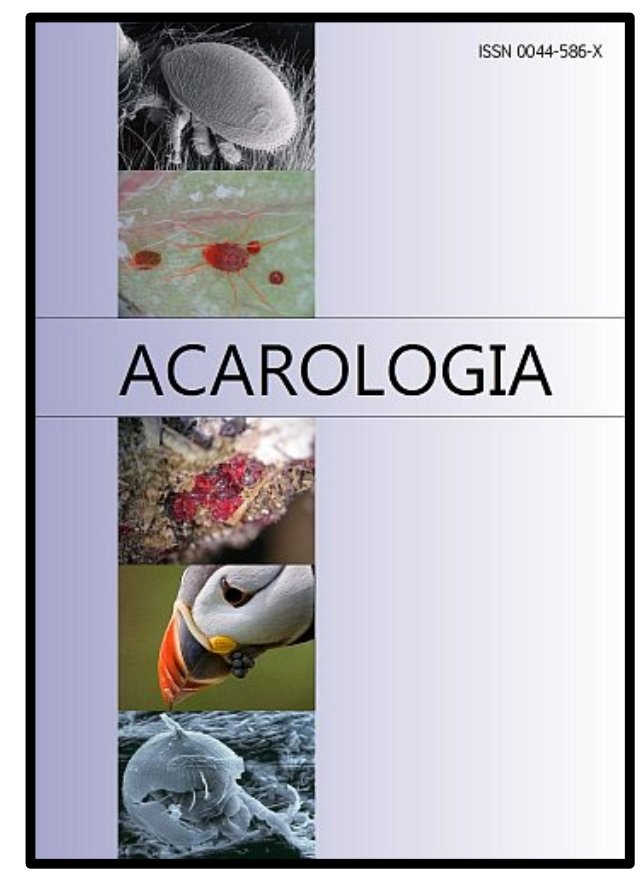

\section{ACAROLOGIA}

A quarterly journal of acarology, since 1959

Publishing on all aspects of the Acari

All information:

http://www1.montpellier.inra.fr/CBGP/acarologia/ acarologia@supagro.inra.fr

\section{OPEN ACCESS}

\section{Acarologia is proudly non-profit, with no page charges and free open access}

Please help us maintain this system by encouraging your institutes to subscribe to the print version of the journal and by sending us your high quality research on the Acari.

Subscriptions: Year 2017 (Volume 57): $380 €$ http://www1.montpellier.inra.fr/CBGP/acarologia/subscribe.php

Previous volumes (2010-2015): $250 € /$ year (4 issues)

Acarologia, CBGP, CS 30016, 34988 MONTFERRIER-sur-LEZ Cedex, France

The digitalization of Acarologia papers prior to 2000 was supported by Agropolis Fondation under the reference ID 1500-024 through the « Investissements d'avenir » programme

(Labex Agro: ANR-10-LABX-0001-01)
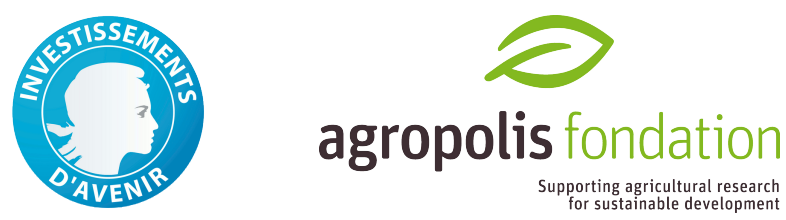

Acarologia is under free license and distributed under the terms of the

Creative Commons-BY-NC-ND which permits unrestricted non-commercial use, distribution, and reproduction in any medium, provided the original author and source are credited. 


\title{
Complementary description of Neoseiulus tunus (De Leon) (Acari: Mesostigmata: Phytoseiidae) and observation on its reproductive strategy
}

\author{
Ana C. C. Cavalcante ${ }^{1}$, Peterson R. Demite ${ }^{1}$, Felipe S. R. Amaral ${ }^{2}$, Antonio C. LofegO ${ }^{3 凶}$ \\ and Gilberto J. de MORAES ${ }^{4}$ \\ (Received 18 October 2016; accepted 30 December 2016; published online 16 May 2017; edited by Serge KREITER) \\ ${ }^{1}$ Instituto Federal Goiano, 75790-000,Urutaí, Goiás, Brazil. anacris.cavalcante@gmail.com, peterson_demite@yahoo.com.br \\ ${ }^{2}$ Programa de Pós-Graduação em Biologia Animal, UNESP, São José do Rio Preto, SP, 15054-000, Brazil. felipesramaral@gmail.com \\ ${ }^{3}$ Departamento de Zoologia e Botânica, UNESP, São José do Rio Preto, 15054-050, São Paulo, Brazil. (凶) aclofego@ig.com.br \\ ${ }^{4}$ Departamento de Entomologia e Acarologia, ESALQ/USP, Piracicaba, 13418-900, São Paulo, Brazil. moraesg@usp.br
}

\begin{abstract}
Neoseiulus tunus (De Leon) is one of the most frequent species of this genus in the Neotropical Region, reported on several plants and localities. In this study, the morphological characterization of various Brazilian populations of this species is presented. Females and males are illustrated. Neoseiulus neotunus (Denmark \& Muma) is here considered a junior synonymn of N. tunus. Thelytokous parthenogenesis is reported for the first time for this species, based on two populations.
\end{abstract}

KEYWORDS - phytoseiid, taxonomic, parthenogenesis, thelytoky

ZOOBANK — B683955E-F7BF-4BF4-879C-CFC4B4E1B3F6

\section{INTRODUCTION}

Neoseiulus Hughes is one of the most diverse genera of the family Phytoseiidae, with around 400 described species (Demite et al., 2014, 2016). One of most frequently reported species in Neotropical Region is Neoseiulus tunus (De Leon). This species was described only from the holotype collected from guava leaves in Trinidad (De Leon, 1967). Soon after the very brief original description of this species, another population, represented by a female (holotype) and a male (allotype), and considered to be different but similar to this species, was described from Piracicaba, São Paulo state, Brazil as Neoseiulus neotunus Denmark \& Muma, 1973. Neoseiulus tunus was later reported from other Caribbean Islands
(Guadeloupe, Jamaica, Marie Galante, Martinique and Trinidad) and from South America (Argentina, Brazil and Peru). In Brazil, it has been found in several states, from the northeast to the south, namely Bahia, Ceará, Goiás, Mato Grosso, Mato Grosso do Sul, Minas Gerais, Paraná, Rio Grande do Sul, Santa Catarina and São Paulo (Demite et al., 2016).

Measurements of the holotype of $N$. tunus were provided by Moraes et al. (2000), whereas complementary descriptions were provided from populations of the French Caribbean islands (Moraes et al., 2000), Argentina (Guanilo et al., 2008a), Brazil (Lofego et al., 2004; Ferla et al., 2011; Gonçalves et al., 2013; Rocha et al., 2015) and Peru (McMurtry and Moraes, 1989; Guanilo et al., 2008b). Due to the great 
similarity between $N$. tunus and $N$. neotunus, the possible synonymy between them was mentioned in the literature (Moraes and Mesa, 1988; Lofego, 1998).

In laboratory colonies of populations identified as N. tunus, initiated with specimens collected from Campinas and Icém, São Paulo state, males were never observed (our unpublished observations). However, males have been found in field samples (wild population) as reported by Furtado et al. (2006) and in this publication. These findings suggest that $N$. tunus may undergo non-obligatory thelytokous parthenogenesis (Suomalainen, 1950; Meêus et al., 2007).

Although pseudo-arrhenotoky (Schulten, 1985) is the most common parthenogenetic reproductive mechanism in phytoseiids, some species reproduce by thelytoky. Wysoki and Bolland (1983) confirmed thelytokous parthenogenesis in Typhlodromus ( $A n-$ thoseius) transvaalensis (Nesbitt) and Neoseiulus salish (Chant \& Hansell). Biological observations under laboratory conditions suggested the occurrence of thelytokous parthenogenesis also in Amblyseius herbicolus (Chant) (Van der Merwe, 1968) (reported as A. largoensis - see Muma \& Denmark, 1970; Blommers, 1976) and Phytoseius intermedius Evans \& Macfarlane (Azevedo et al., 2016).

The objective of this study is to present morphological information about various Brazilian populations of $N$. tunus, with illustrations of the female and the male, as well as an evaluation of reproductive strategy of two populations of N. tunus. Another aim of this work was to evaluate the possible synonymy between $N$. tunus and $N$. neotunus.

\section{MATERIALS AND METHODS}

\section{Taxonomy}

The holotype females of $N$. tunus and N. neotunus were examined under phase contrast microscopy at FSCA, Gainesville, Florida, USA, where they are deposited. Additionally, specimens deposited in the mite collections of Departamento de Zoologia e Botânica, UNESP (Universidade Estadual Paulista), São José do Rio Preto and of Departamento de Entomologia e Acarologia, ESALQ-USP (Escola Superior de Agricultura "Luiz de Queiroz", Universidade de São Paulo), Piracicaba, both in São Paulo state, Brazil, were also examined under phase contrast microscopy. All specimens examined were from samples collected in field.

The classification system used was that of Chant and McMurtry (2007). Dorsal and ventral setal nomenclature were that of Rowell et al. (1978) and Chant and Yoshida-Shaul (1991), respectively. The notation for gland pores (solenostomes) or lyrifissures (poroids) are based on Athias-Henriot (1975). Measurements were done with the use of a graduate eyepiece. All measurements are given in micrometers. Illustrations were made using a drawing tube attached to the microscope.

\section{Parthenogenesis}

Tests were performed to verify the reproductive strategy of two populations of $N$. tunus under controlled conditions. The experiments were conducted at $28 \pm 1{ }^{\circ} \mathrm{C}, 80 \pm 10 \%$ relative humidity and $12 \mathrm{~h}$ of daily photophase, in a growth chamber.

\section{Establishment of colonies}

Colonies were established from mites collected from two sources:

- Campinas (CAMP): from bell pepper, Capsicum annuum L. (Solanaceae), placed in an urban forest fragment in Campinas, São Paulo state (22 52'04"S; $\left.47^{\circ} 04^{\prime} 41^{\prime \prime} \mathrm{W}\right)$.

- Icém (ICEM): from Trichilia casareti D. DC. (Meliaceae), growing naturally in a forest fragment at Icém, São Paulo state (20²0’48"S; 49¹5'49"W).

About 300 predators were collected and used to establish the colony for each population. Colonies were maintained in rearing units similar to those described by McMurtry and Scriven (1965), consisting of a tray containing a foam mat overlaid by a plastic plate onto which the predators were placed. The foam mat was maintained permanently wet with distilled water, to prevent predators from escaping. Cattail pollen (Typha domingensis Persoon) and Aleuroglyphus ovatus (Troupeau) (Acari: Astigmatina: Acaridae) were used as food sources in both stock colonies, maintained in a room where environmental conditions were not controlled $(24-27$ 
${ }^{\circ} \mathrm{C}, 60-80 \%$ relative humidity and about $12 \mathrm{~h}$ photophase).

\section{Experimental procedure}

Thirty newly hatched larvae of each $N$. tunus population were randomly taken from the respective stock colony and each was placed in an experimental unit. Each experimental unit consisted of a plastic container $(2.6 \mathrm{~cm}$ diameter $\times 1.5 \mathrm{~cm}$ in height) whose base was covered with a layer of solidified paste of a mixture of gypsum and activated charcoal (9v: 1v) (Abbatiello, 1965). The edge of each unit was coated with insect glue to prevent the mites from escaping and water was added daily to the unit to maintain humidity high. Each predator was fed with an excess of larvae or protonymphs of Aleuroglyphus ovatus (Troupeau), added daily to each unit.

Units were evaluated every 24 hours for 12 consecutive days to determine adult emergence, preoviposition and oviposition. At each day, eggs obtained by the females of each population were put together into a new unit, feeding them as mentioned for the previous generation. They were maintained until reaching the adult stage to be sexed. Mite handling and observations were done under a stereomicroscope (magnification 30x).

\section{RESULTS AND DISCUSSION}

\section{Taxonomy}

\section{Neoseiulus tunus (De Leon)}

(Figure 1)

Typhlodromips tunus De Leon, 1967: 29; Moraes et al., 1986: 151.

Amblyseius tunus McMurtry and Moraes, 1989: 181.

Neoseiulus tunus Lofego, 1998: 45; Chant and McMurtry, 2003: 21, 2007: 31; Moraes et al., 2004: 148; Demite et al., 2016.

Typhlodromips neotunus Denmark \& Muma, 1973: 255 (new synonym).
Amblyseius neotunus Moraes and Mesa, 1988: 155.

Neoseiulus neotunus Chant and McMurtry, 2003: 21; 2007: 29; Moraes et al., 2004: 135; Demite et al., 2016.

Female.

Measurements given in Table 1.

Dorsum - Idiosomal setal pattern (Chant and Yoshida-Shaul, 1991): 10A:9B/JV-3:ZV. Dorsal shield reticulate, except for a smooth transverse band at level of Z4; with 15 pairs of lyrifissures (id1, idx, id2, id4, id6, is1, idm1, idm2, idm3, idx', idm4, idm6, idl1, idl3 and idl4) and seven pairs of pores (gd1, gd2, gd4, gd5, gd6, gd8 and gd9). Is not easy to see all pores and lyrifissures in an unique specimen. Setae j1, j3, z2, z4, Z1, Z4, Z5, s4, S2 and S4 serrate; $j 4, j 5, j 6, z 5, S 5, r 3$ and $R 1$ lightly serrate and J5 smooth.

Venter - Sternal shield with three pairs of setae and two pairs of lyrifissures; st4 on metasternal plate. Genital shield smooth. With two pairs of metapodal plates. Ventrianal shield constricted between JV2 and anus levels, smooth; with three pairs of pre-anal setae $(J V 1, J V 2$ and $Z V 2)$ and a pair of pores mesad of $J V 2$. Four pairs of opisthogastric setae on unsclerotized cuticle (JV4, JV5, ZV1 and ZV3). All ventral setae smooth, except JV5 serrate.

Peritreme - Extending anteriorly to level of j1.

Spermatheca - Calyx cup-shaped; atrium inconspicuous.

Chelicera - Movable digit with three teeth in addition to apical tooth; fixed digit with five-seven teeth in addition to apical tooth and pilus dentilis.

Legs - Macrosetae smooth and with tiny distal knobs. Chaetotatic formula of genu II: 2-2/0-2/0-1 and of genu III: 1-2/1-2/0-1.

$$
\begin{gathered}
\text { Male } \\
(n=10, \text { all collected in this study }) .
\end{gathered}
$$

Dorsum - Dorsal shield ornamentation as in female, 241 (230-255) long, 159 (150-171) wide at level of s4; setae: $j 119$ (15-20), j3 22 (20-25), j4 14 (11-16), 


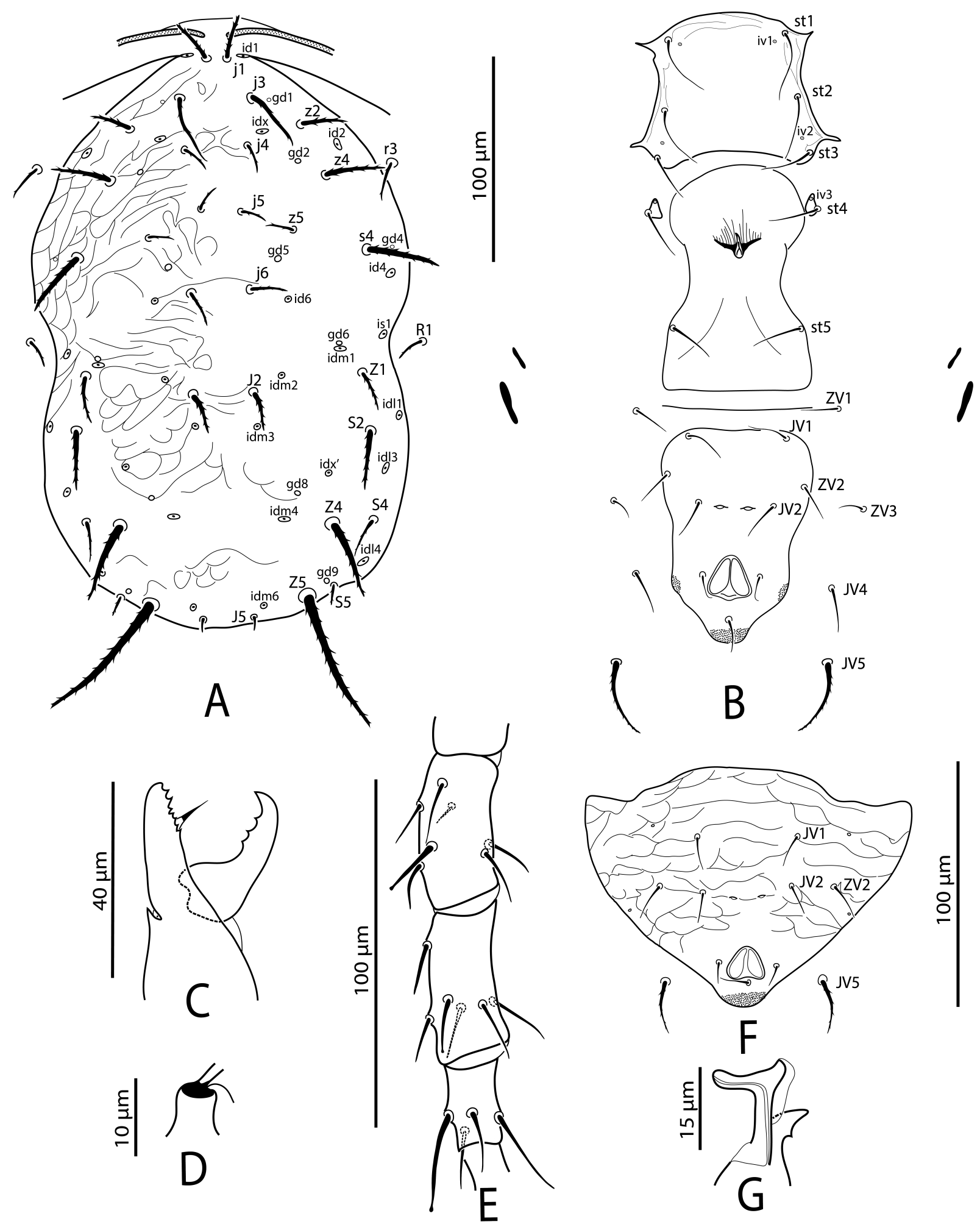

FIGURE 1: Neoseiulus tunus (Denmark \& Muma): Female: A - Dorsal shield; B - Ventral idiosoma; C - Chelicera; D - Spermatheca; E Genu, tibia and basitarsus of leg IV; Male: F - Ventrianal shield; G - Spermatodactyl. 
TABLE 1: Measures of holotypes of Neoseiulus tunus (De Leon) and N. neotunus (Denmark \& Muma) and measures (mean and range) of N. tunus females from several regions from Brazil (this work) and reported in other localities (previous works).

\begin{tabular}{|c|c|c|c|c|c|c|}
\hline \multirow{3}{*}{ Character } & \multicolumn{3}{|c|}{ This work } & \multicolumn{3}{|c|}{ Previous works } \\
\hline & Neoseiulus tunus* & Neoseiulus neotunus* & Other Brazilian & Moraes et al. (2000) & Guanilo et al. (2008a) & Guanilo et al. (2008b) \\
\hline & (Trinidad) & (Brazil) & specimens $(n=40)$ & (French Antilles) & (Argentina) & (Peru) \\
\hline$\overline{\mathrm{DSL}}$ & 288 & 293 & $288(270-315)$ & $289(277-297)$ & $290(275-300)$ & $283(280-285)$ \\
\hline DSW & 166 & 170 & $177(168-192)$ & $154(150-156)$ & $181(175-185)$ & $174(170-178)$ \\
\hline j1 & 23 & 24 & $24(20-27)$ & $23(19-26)$ & $23(21-25)$ & $22(21-23)$ \\
\hline j3 & 28 & 30 & $28(25-31)$ & $24(19-27)$ & $29(28-30)$ & $27(25-29)$ \\
\hline j4 & 13 & 12 & $14(11-17)$ & $14(13-16)$ & $14(12-16)$ & $14(13-15)$ \\
\hline$j 5$ & 16 & 13 & $14(11-16)$ & $16(14-18)$ & $14(14-15)$ & $16(15-18)$ \\
\hline j6 & 20 & 19 & $19(14-24)$ & $19(18-21)$ & $20(19-22)$ & $20(20-21)$ \\
\hline$J 2$ & 20 & 21 & $21(16-27)$ & $21(18-24)$ & $26(22-28)$ & 22 \\
\hline J5 & 7 & 7 & $8(7-9)$ & $9(8-10)$ & $8(7-10)$ & 7 \\
\hline$\geqslant 2$ & 20 & 24 & $23(19-27)$ & $23(21-24)$ & $25(24-27)$ & $20(20-21)$ \\
\hline 24 & 30 & 38 & $31(27-37)$ & $27(23-31)$ & 35 & $27(25-30)$ \\
\hline 25 & 16 & 18 & $15(11-18)$ & $18(16-19)$ & $16(15-16)$ & $15(15-16)$ \\
\hline$Z 1$ & 24 & 27 & $25(21-31)$ & $25(24-26)$ & $29(26-32)$ & $26(25-27)$ \\
\hline Z4 & 43 & 49 & $45(41-54)$ & $40(39-40)$ & 47 & $41(40-41)$ \\
\hline$Z 5$ & 64 & 69 & $70(63-80)$ & $66(64-68)$ & $70(67-72)$ & $67(65-68)$ \\
\hline st & 36 & 38 & $38(33-44)$ & $35(34-37)$ & $42(42-43)$ & $37(36-37)$ \\
\hline$\$ 2$ & 31 & 36 & $34(29-40)$ & $33(32-34)$ & $41(38-43)$ & $32(31-33)$ \\
\hline 54 & 19 & 22 & $20(17-25)$ & $20(19-21)$ & $25(23-30)$ & $20(18-21)$ \\
\hline 55 & 12 & 14 & $14(10-20)$ & $13(11-16)$ & $16(17-20)$ & 13 \\
\hline$r 3$ & 24 & 22 & $25(22-30)$ & $21(21-22)$ & $26(23-30)$ & $23(20-25)$ \\
\hline R1 & 14 & 19 & $17(14-20)$ & $17(16-18)$ & $18(17-20)$ & $16(15-16)$ \\
\hline$s t 1-s t 3$ & 54 & 59 & $58(55-62)$ & $56(55-56)$ & $54(53-55)$ & $57(55-58)$ \\
\hline$s t 2-s t 2$ & 62 & 66 & $65(61-70)$ & $62(60-64)$ & $62(60-63)$ & $63(61-65)$ \\
\hline$s t 5-s t 5$ & 60 & 56 & $62(58-69)$ & $58(56-60)$ & $61(60-63)$ & $61(58-63)$ \\
\hline VSL & 98 & 106 & $104(95-117)$ & $100(99-100)$ & 97 (90-105) & $99(98-100)$ \\
\hline VSWWant & 70 & 72 & $73(66-80)$ & $67(63-72)$ & 75 & $70(65-75)$ \\
\hline VSWpost & 54 & 56 & $58(51-65)$ & $52(52-53)$ & $62(60-63)$ & $56(55-58)$ \\
\hline Calyx & 6 & 7 & $7(6-9)$ & $9(8-10)$ & $7(6-9)$ & $10(8-11)$ \\
\hline MDL & 31 & 30 & $28(25-30)$ & $27(26-27)$ & $32(31-33)$ & 30 \\
\hline MD teeth & 3 & 3 & 3 & 3 & 3 & 3 \\
\hline FDL & & 27 & $29(26-31)$ & $27(26-27)$ & 30 & $34(33-35)$ \\
\hline FD teeth & 8 & 6 & $7(5-7)$ & 8 & 6 & 7 \\
\hline SgeIV & 22 & 19 & $20(16-24)$ & $20(19-21)$ & $20(20-21)$ & $22(21-22)$ \\
\hline StiIV & 19 & 17 & $18(15-20)$ & $19(16-23)$ & & $18(17-19)$ \\
\hline StIV & 32 & 29 & $31(25-36)$ & $25(23-29)$ & $32(30-33)$ & $32(31-32)$ \\
\hline
\end{tabular}

width at level anus; MDL: Movable digit length; FDL: Fixed digit length.

j5 14 (12-17), j6 16 (13-21), J2 17 (14-21), J5 8 (7-9), z2 $19(17-22), z 423(20-26), z 514(12-18)$, Z1 $20(18-25)$, Z4 31 (30-35), Z5 40 (35-47), s4 28 (24-30), S2 25 (20-28), S4 17 (15-19), S5 14 (12-15), r3 20 (18-21), $R 114$ (12-15). Setae $r 3$ and $R 1$ on dorsal shield. Setae $j 1, j 3, z 2, z 4, Z 1, Z 4, Z 5, s 4, S 2$ and $S 4$ serrate; $j 4$, $j 5, j 6, z 5, S 5, r 3$ and $R 1$ lightly serrate and $J 5$ smooth.

Venter - Sternogenital shield smooth; ventrianal shield subtriangular, reticulate, 101 (92-113) long and 134 (125-145) wide at anterior corners, with three pairs of pre-anal setae (JV1, JV2 and $Z V 2$ ), two pairs of lyrifissures and one pair of pores postero-mesad of JV2; JV5 23 (21-27). All ventral setae smooth, except $J V 5$ serrate.

Peritreme - Extending anteriorly to $j 1$.

Spermatodactyl — Shaft L-shaped, 14 (12-16) long.

Legs - Macrosetae smooth and with tiny distal 
knobs; lengths: SgeIV 14 (12-15), StiIV 14 (13-16), StIV 24 (21-28). Chaetotatic formula of genu II: 22/0-2/0-1 and of genu III: 1-2/1-2/0-1.

Material Examined - Holotype female of $N$. tunus, on Psidium guajava L. (Myrtaceae), October 1963, Tunapuna, Trinidad; holotype female of $N$. neotunus, on Pothomorphe sidaefolia (Link \& Otto) Miq. (Piperaceae), March 1967, Piracicaba, São Paulo state, Brazil. Additional specimens: 1 female, on Hevea brasiliensis (Müll Arg.) (Euphorbiaceae), March 2002, Nhandeara $\left(20^{\circ} 42^{\prime} \mathrm{S}, 49^{\circ} 58^{\prime} \mathrm{W}\right)$, São Paulo, Brazil; 1 female, on Cedrela fissilis Vell. (Meliaceae), February 2003, São José do Rio Preto ( $\left.20^{\circ} 46^{\prime} \mathrm{S}, 4^{\circ} 19^{\prime} \mathrm{W}\right)$, São Paulo, Brazil; 1 female, on Croton floribundus Spreng. (Euphorbiaceae), São José do Rio Preto $\left(20^{\circ} 46^{\prime} \mathrm{S}, 49^{\circ} 19^{\prime} \mathrm{W}\right)$, São Paulo, Brazil; 1 female, on Copaifera langsdorfii Desf. (Leguminosae), July 2004 , Itiquira $\left(17^{\circ} 23^{\prime} \mathrm{S}, 54^{\circ} 42^{\prime} \mathrm{W}\right)$, Mato Grosso, Brazil; 2 females, on Actinostemon communis (Müll. Arg.) Pax. (Euphorbiaceae), July 2007, Taquaritinga $\left(21^{\circ} 24^{\prime} \mathrm{S}, 48^{\circ} 41^{\prime} \mathrm{W}\right)$, São Paulo, Brazil; 2 females, on A. communis, July 2007, Barretos $\left(20^{\circ} 38^{\prime} \mathrm{S}, 48^{\circ} 45^{\prime} \mathrm{W}\right)$, São Paulo, Brazil; 2 females and 1 male, on A. communis, July 2007, Turmalina $\left(20^{\circ} 00^{\prime} \mathrm{S}, 50^{\circ} 26^{\prime} \mathrm{W}\right)$, São Paulo, Brazil; 1 female and 1 male, A. communis, July 2007, Matão (21 $\left.{ }^{\circ} 37^{\prime} \mathrm{S}, 48^{\circ} 32^{\prime} \mathrm{W}\right)$, São Paulo, Brazil; 1 female, on A. communis, July 2007 , Novo Horizonte $\left(21^{\circ} 03^{\prime} \mathrm{S}\right.$, $\left.49^{\circ} 18^{\prime} \mathrm{W}\right)$, São Paulo, Brazil; 1 female and 1 male, on A. communis, April 2008, Novo Horizonte $\left(21^{\circ} 03^{\prime} \mathrm{S}\right.$, $49^{\circ} 18^{\prime}$ W), São Paulo, Brazil; 1 female, A. communis, April 2008, Palestina $\left(20^{\circ} 19^{\prime} \mathrm{S}, 49^{\circ} 30^{\prime} \mathrm{W}\right)$, São Paulo, Brazil; 3 males, Croton urucurana Baill. (Euphorbiaceae), March 2008, Matão ( $\left.21^{\circ} 37^{\prime} S, 48^{\circ} 32^{\prime} W\right)$, São Paulo, Brazil; 1 female, on Hevea brasiliensis (Müll. Arg.) (Euphorbiaceae), October 2008, Igrapiúna $\left(13^{\circ} 48^{\prime} \mathrm{S}, 39^{\circ} 10^{\prime} \mathrm{W}\right)$, Bahia, Brazil; 1 female, on Schefflera sp. (Araliaceae), October 2008, Igrapiúna $\left(13^{\circ} 48^{\prime} \mathrm{S}, 39^{\circ} 10^{\prime} \mathrm{W}\right)$, Bahia, Brazil; 1 female, Pouteria torta (Mart.) Pierre (Sapotacceae), December

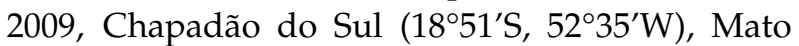
Grosso do Sul, Brazil; 1 female, Fuirena umbellata Rottb. (Cyperaceae), January 2010, Chapadão do Sul $\left(18^{\circ} 51^{\prime} \mathrm{S}, 52^{\circ} 35^{\prime} \mathrm{W}\right)$, Mato Grosso do Sul, Brazil; 1 female, Didymopanax vinosus (Cham. \& Schltdl.) Marchal (Araliaceae), December 2009, Chapadão do
Sul $\left(18^{\circ} 51^{\prime} \mathrm{S}, 5^{\circ} 35^{\prime} \mathrm{W}\right)$, Mato Grosso do Sul, Brazil; 1 female, Campomanesia pubescens (Mart. ex DC.) O.Berg (Myrtaceae), December 2009, Chapadão do Sul $\left(18^{\circ} 51^{\prime} \mathrm{S}, 52^{\circ} 35^{\prime} \mathrm{W}\right)$, Mato Grosso do Sul, Brazil; 1 female, Miconia albicans (Sw.) Steud. (Melastomataceae), December 2009, Chapadão do Sul (18 $51^{\prime}$ 'S, $52^{\circ} 35^{\prime} \mathrm{W}$ ), Mato Grosso do Sul, Brazil; 1 female, Bahuinia sp. (Leguminosae), December 2009, Chapadão do Céu $\left(18^{\circ} 15^{\prime} \mathrm{S}, 52^{\circ} 44^{\prime} \mathrm{W}\right)$, Goiás, Brazil; 1 female, Stryphnodendron adstringens (Mart.) Coville (Leguminosae), December 2009, Tupaciguara (18 $\left.31^{\prime} \mathrm{S}, 48^{\circ} 54^{\prime} \mathrm{W}\right)$, Minas Gerais, Brazil; 1 female, M. albicans, Tupaciguara $\left(18^{\circ} 31^{\prime} \mathrm{S}, 48^{\circ} 54^{\prime} \mathrm{W}\right)$, Minas Gerais, Brazil; 1 female and 1 male, on Myrcia palustris DC. (Myrtaceae), April 2012, Teutônia (29²3'S, $\left.51^{\circ} 48^{\prime} \mathrm{W}\right)$, Rio Grande do Sul, Brazil; 2 females, on Myrcia palustris DC. (Myrtaceae), April 2012, Teutônia, Rio Grande do Sul, Brazil; 2 males, on Myrciaria plinioides D. Legrand (Myrtaceae), April 2012, Lajeado $\left(29^{\circ} 26^{\prime} \mathrm{S}, 51^{\circ} 57^{\prime} \mathrm{W}\right)$, Rio Grande do Sul, Brazil; 3 females and 1 male, on Myrciaria plinioides D. Legrand (Myrtaceae), December 2012, Lajeado, Rio Grande do Sul, Brazil; 1 female, on Alibertia edulis (Rich) A. Rich (Rubiaceae), February 2015, Urutaí $\left(17^{\circ} 28^{\prime} \mathrm{S}, 48^{\circ} 12^{\prime} \mathrm{W}\right)$, Goiás, Brazil; 1 female, on Cecropia pachystachya Trécul. (Urticaceae),

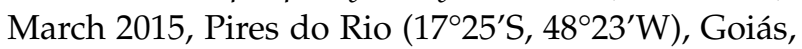
Brazil; 1 female, on Dilodendron bipinnatum Radlk. (Sapindaceae), April 2015, Caldas Novas (17³9'S, $\left.48^{\circ} 44^{\prime} \mathrm{W}\right)$, Goiás, Brazil; 2 females, on Rudgea viburnoides (Cham.) Benth. (Rubiaceae), May 2015, Santa Cruz de Goiás ( $\left.17^{\circ} 20^{\prime} \mathrm{S}, 48^{\circ} 37^{\prime} \mathrm{W}\right)$, Goiás, Brazil; 1 female, on Chomelia martiana Mull. Arg.

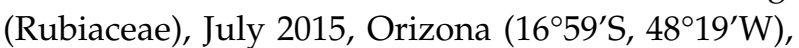
Goiás, Brazil; 2 females, on unidentified plant, April

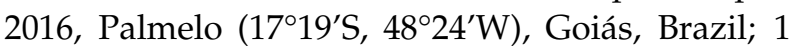
female, Hymenaea sp. (Leguminosae), April 2016,

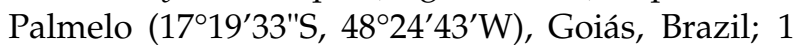
female, on Piptocarpha rotundifolia (Less.) Baker (Compositae), June 2016, Urutaí $\left(17^{\circ} 24^{\prime} \mathrm{S}, 48^{\circ} 04^{\prime} \mathrm{W}\right)$, Goiás, Brazil.

\section{Remarks}

Denmark \& Muma (1973) distinguished Neoseiulus neotunus from $N$. tunus based on setal ornamentantion, shape of spermatheca and of leg IV 
macrosetae. Our examination of both holotypes and of the additional specimens from Brazil led us to conclude that the differences mentioned in the original description of $N$. neotunus correspond to intraspecific variations. All dorsal setae, except $J 5$ are serrate and macrosetae of leg IV have the tips with minute knobs in both holotypes and in the additional specimens examined. The difference in the shape of the calyx of the spermatheca mentioned in the original description of $N$. neotunus might be due to the slightly different position in the mounted specimens. Additionally, the measurements include in this work and those available in the literature, for specimens from different populations are similar (Table 1). The only morphological difference observed between the holotypes was the number of teeth on fixed cheliceral digit (8 and 6 in the holotypes of $N$. tunus and N. neotunus, respectively). This variation has been also observed on different populations (Table 1). However, variations in number of cheliceral teeth is well known to occur in phytoseiids. In one of the extreme cases, Lofego et al. (2009) observed the number of teeth on the fixed digit of Neoseiulus benjamini (Schicha) to vary from 6 to 10 within a same population (in some specimens, between right and the left chelicerae). It is concluded that $N$. neotunus is a junior synonym of N. tunus.

\section{Parthenogenesis}

About $83.0 \%$ of the CAMP ( 25 specimens) population and $96.6 \%$ of the ICEM (29 specimens) population reached the adult stage, all being females. Emergence of the adult and pre-oviposition period were respectively $5.2 \pm 0.21$ and $3.9 \pm 0.32$ days for the CAMP $(\mathrm{n}=24)$ population and $4.1 \pm 0.18$ and $2.7 \pm 0.16$ days for the ICEM $(n=26)$ population. Daily oviposition rates were $0.8 \pm 0.06$ and $1.0 \pm 0.06$ eggs / female for the CAMP $(\mathrm{n}=24)$ and $\operatorname{ICEM}(n=26)$ populations, respectively. All of these were viable and produced only females, strongly suggesting that $N$. tunus reproduces by thelytokous parthenogenesis.

However, the occurrence of males of this species in field collected populations indicates that deuterotokous parthenogenesis as reproductive mecha- nism in this species should not be discarded. Reasons for the occurrence of parthenogenesis are not always known (Tilquin and Kokko, 2016). For invertebrates, including arthropods, studies have reported the modulation of parthenogenesis by abiotic and biotic factors, when this is an option for a sexual reproduction (see Tilquin and Kokko, 2016). Phytoseiids often experience various abiotic and biotic types of pressures (e.g. temperature, humidity, agrochemicals, light incidence, cannibalism, food availability, pathogens) under field and laboratory conditions, which can affect physiological and genetic mechanisms (see Ghazy et al., 2016).

One of the possible biotic factors to be considered is interaction with endosymbionts, which has been reported for mites and other arthropods (Enigl and Schausberger, 2007; Zug and Hammerstein, 2012). Several arthropods have been reported infected by endosymbiotic bacteria, such as Wolbachia and Cardinium (Breeuwer and Jacobs, 1996; Kostas and O'Neill, 1998; Weeks et al., 2003; Wu and Hoy, 2012). These endosymbionts have been associated with reproductive manipulation, such as cytoplasmic incompatibility, parthenogenesis and feminization (Weeks et al., 2001; Kageyama et al., 2012). In a study conducted by Zchori-Fein et al. (2001), thelytokous parthenogenesis modulated by Cardinium hertigii was demonstrated in wasp parasitoids of the genus Encarsia (Hymenoptera: Aphelinidae). Weeks and Breeuwer (2001) reported the induction of parthenogenesis by Wolbachia in Bryobia praetiosa Koch (Tetranychidae). These facts suggest that endosymbionts could also modulate the reproductive mechanism of $N$. tunus.

Under a pragmatic point of view, thelytokous reproduction may facilitate the persistence of a naturally evolved or an artificially selected characteristic (e.g. ability to diapause, tolerance to temperature variation or pesticides) in organisms released in the field for biological control purposes (Hoy and Cave, 1986). Released females would not interbreed with indigenous individuals, which could attenuate with time the predetermined characteristic.

In summary, N. neotunus is concluded to be a junior synonym of $N$. tunus, a species that can reproduce parthenogenetically, although in at least some 
populations male specimens can be found. Complementary studies are necessary to determine factors interfering with its reproductive mechanisms and leading to the occasional production of males.

\section{ACKNOWLEDGEMENTS}

This work was partially financed by "Fundação de Amparo a Pesquisa do Estado de São Paulo" (FAPESP: Proc. nr. 04/04820-3, 06/55725-6, 06/57868-9 and 11/08941-3) and CNPq/FAPEG winthin the "Desenvolvimento Científico e Tecnológico Regional (DCR)" Program (Proc. nr. 303016/2014-0). A.C. Lofego and G.J. de Moraes are CNPq researchers (Proc. nr. 304562/2015-7 and 304930/2014-8, respectively).

\section{REFERENCES}

Abbatiello M.J. 1965 - A culture chamber for rearing soil mites - Turtox News, 43(7):162-164.

Athias-Henriot C. 1975 - Nouvelle notes sur les Amblyseiini II. Le rélève organotaxique de la face dorsal adulte (Gamasides protoadeniques, Phytoseiidae) Acarologia, 17(1): 20-29.

Azevedo L.H., Castilho R. de C., Moraes J.G. de. 2016 - Suitability of the litchi erineum mite, Aceria litchii (Keifer), as prey for the mite Phytoseius intermedius Evans \& MacFarlane (Acari: Eriophyidae, Phytoseiidae) - Syst. Appl. Acarol., 21(3): 270-278. doi:10.11158/saa.21.3.2

Blommers L. 1976 - Some Phytoseiidae (Acarina: Mesostigmata) from Madagascar, with descriptions of eight new species and notes on their biology — Bijdragen tot Dierkunde, 46(1): 80-106.

Breeuwer J.A.J., Jacobs G. 1996 - Wolbachia: intracellular manipulators of mite reproduction - Exp. Appl. Acarol., 20(8): 421-434. doi:10.1007/BF00053306

Chant D.A., McMurtry J.A. 2003 - A review of the subfamily Amblyseiinae Muma (Acari: Phytoseiidae): Part I. Neoseiulini new tribe - Int. J. Acarol., 29(1): 3-46. doi:10.1080/01647950308684319

Chant D.A., McMurtry J.A. 2007 - Illustrated keys and diognoses for the genera and subgenera of the Phytoseiidae of the world (Acari: Mesostigmata) - West Bloomfield: Indira Publishing House. pp. 220.

Chant D.A., Yoshida-Shaul, E. 1991 - Adult ventral setal patterns in the family Phytoseiidae (Acari: Gamasina) - Int. J. Acarol., 17(3): 187-199. doi:10.1080/01647959108683906
De Leon D. 1967. Some mites of the Caribbean Area. Part I. Acarina on plants in Trinidad, West Indies. Lawrence: Allen Press Inc. pp.66

Demite P.R., McMurtry J.A., Moraes G.J. de. 2014 - Phytoseiidae Database: a website for taxonomic and distributional information on phytoseiid mites (Acari) - Zootaxa, 3795(5): 571-577. doi:10.11646/zootaxa.3795.5.6

Demite P.R., Moraes G.J. de, McMurtry J.A., Denmark H.A., Castilho R. de C. - Phytoseiidae Database [Internet] - [09 September 2016]. Brazil: ESALQ/USP; Available from: http:/ / www.lea.esalq.usp.br/phytoseiidae

Denmark H.A., Muma M.H. 1973 — Phytoseiid mites of Brazil (Acarina: Phytoseiidae) - Rev. Bras. Biol., 33(2): 235-276.

Enigl M., Schausberger P. 2007 - Incidence of the endosymbionts Wolbachia, Cardinium and Spiroplasma in phytoseiid mites and associated prey - Exp. Appl. Acarol., 42(2):75-85. doi:10.1007/s10493-007-9080-3

Ferla N.J., Johann L., Klock C., Majolo F., Botton M. 2011 - Phytoseiid mites (Acari: Phytoseiidae) from vineyards in Rio Grande do Sul State, Brazil - Zootaxa, 2976: 15-31.

Furtado I.P., Moraes G.J de, Kreiter S., Knapp M. 2006 - Search for effective natural enemies of Tetranychus evansi in south and southeast Brazil - Exp. Appl. Acarol., 40:157-174. doi:10.1007/s10493-006-9045-y

Ghazy N.A., Osakabe M., Negm M.W., Schausberger P., Gotoh T., Amano H. 2016 - Phytoseiid mites under environmental stress - Biol. Control, 96: 120-134. doi:10.1016/j.biocontrol.2016.02.017

Gonçalves D., Silva G.L. da, Ferla N.J. 2013 — Phytoseiid mites (Acari) associated with yerba mate in southern Brazil, with description of a new species - Zootaxa, 3746(2): 357-371.

Guanilo A.D., Moraes G.J. de, Toledo S., Knapp M. 2008a - Phytoseiid mites (Acari: Phytoseiidae) from Argentina, with description of a new species - Zootaxa, 1884: 1-35.

Guanilo A.D., Moraes G.J.de, Knapp M. 2008b - Phytoseiid mites (Acari: Phytoseiidae) of the subfamily Amblyseiinae Muma from Peru, with description of four new species - Zootaxa, 1880: 1-47.

Hoy M.A., Cave F.E. 1986 - Screening for thelytoky in the parahaploid phytoseiid Metaseiulus occidentalis (Nesbitt) - Exp. Appl. Acarol., 2(3): 273-276. doi:10.1007/BF01193959

Kageyama D., Narita S., Watanabe M. 2012 — Insect Sex Determination manipulated by their endosymbionts: incidences, mechanisms and implications - Insects, 3: 161-199. 
Kostas B., OŃeill S. 1998 - "Wolbachia" Infections and Arthropod Reproduction - BioScience, 48 (4): 287293.

Lofego A.C., Demite P.R., Kishimoto R.G., Moraes G.J.de. 2009 - Phytoseiid mites on grasses in Brazil (Acari: Phytoseiidae) - Zootaxa, 2240: 41-59.

Lofego A.C., Moraes G.J. de, Castro L.A.S. 2004 - Phytoseiid mites (Acari: Phytoseiidae) on Myrtaceae in State of São Paulo, Brazil — Zootaxa, 516: 1-18.

Lofego, A.C. 1998 - Caracterização morfológica e distribuição geográfica das espécies de Amblyseiinae (Acari: Phytoseiidae) no Brasil [MSc Dissertation] São Paulo: Universidade de São Paulo. pp. 167 + viii.

McMurtry J.A., Moraes G.J. de 1989 — Some phytoseiid mites from Peru with descriptions of four new species (Acari: Phytoseiidae) — Int. J. Acarol., 15(3): 179-188. doi:10.1080/01647958908683843

McMurtry J.A., Scriven G.T. 1965 - Insectary production of phytoseiid mites - J. Econ. Entomol., 58(2): 282284. doi:10.1093/jee/58.2.282

Meêus T.de, Prugnolle F., Agnew P. 2007 - Asexual reproduction: Genetics and evolutionary aspects - Cell. Mol. Life Sci., 64(11): 1355-1372. doi:10.1007/s00018007-6515-2

Moraes G.J. de, McMurtry J.A., Denmark H.A. 1986 A catalog of the mite family Phytoseiidae: references to taxonomy, synonymy, distribution and habitat Brasilia: Embrapa - DDT. pp. 353.

Moraes G.J.de, Kreiter S., Lofego A.C. 20001999 — Plant mites (Acari) of the French Antilles. 3. Phytoseiidae (Gamasida) - Acarologia, 40(3): 237-264.

Moraes G.J. de, Mesa, N.C. 1988 - Mites of the family Phytoseiidae (Acari) in Colombia, with descriptions of three new species - Int. J. Acarol., 14(2): 71-88. doi:10.1080/01647958808683790

Moraes G.J.de, McMurtry J.A., Denmark H.A., Campos C.B. 2004 - A revised catalog of the mite family Phytoseiidae - Zootaxa, 434: 1-494.

Muma M.H., Denmark H.A. 1970 - Phytoseiidae of Florida. Arthropods of Florida and neighboring land areas. 6-Gainesville: Florida Department of Agriculture and Consumer Services, Division of Plant Industry. pp. 150.

Rocha M. dos S., Silva G.L. da, Silva J.O. da, Freitas E.M. de, Ferla N.J. 2015 - Phytoseiid mites (Acari: Phytoseiidae) in the northeastern coastal region of the Rio Grande do Sul State, Brazil - Neotrop. Biodivers., 1(1): 22-35. doi:10.1080/23766808.2015.1052230

Rowell H.J., Chant D.A., Hansell R.I.C. 1978 - The determination of setal homologies and setal patterns on the dorsal shield in the family Phytoseiidae (Acarina:
Mesostigmata) - Can. Entomol., 110(8): 859-876. doi:10.4039/Ent110859-8

Schulten G.G.M. 1985 — Pseudo-arrhenotoky — In: Helle W., Sabelis M.W. (Eds). Spider mites: their biology, natural enemies and control (World Crop Pests, 1B). Amsterdam: Elsevier, p. 67-71.

Suomalainen E. 1950 - Parthenogenesis in animals - Adv. Genet., 3: 193-253. doi:10.1016/S00652660(08)60086-3

Tilquin A., Kokko H. 2016 - What does the geography of parthenogenesis teach us about sex? - Phil. Trans. R. Soc. B., 371:20150538. doi:10.1098/rstb.2015.0538

Van der Merwe G.G. 1968 - A taxonomic study of the family Phytoseiidae (Acari) in South Africa with contributions to the biology of two species - S. Afr. Dep. Agric. Tec. Serv., Entomol. Mem. 18: 1-198.

Weeks A.R, Velten R., Stouthamer R. 2003 - Incidence of a new sex-ratio-distorting endosymbiotic bacterium among arthropods - Proc. R. Soc. Lond. B, 270(1526): 1857-1865. doi:10.1098/rspb.2003.2425

Weeks A.R., Breeuwer J.A. 2001 - Wolbachia-induced parthenogenesis in a genus of phytophagous mites - Proc. R. Soc. Lond. B, 268(1482): 2245-2251. doi:10.1098/rspb.2001.1797

Weeks A.R., Marec F., Breeuwer J.A. 2001 - A mite species that consists entirely of haploid females - Science, 292(5526): 2479-2482.

Wu K., Hoy M. A. 2012 - Cardinium is associated with reproductive incompatibility in the predatory mite Metaseiulus occidentalis (Acari: Phytoseiidae) - J. Invertebr. Pathol., 110(3): 359-365. doi:10.1016/j.jip.2012.03.027

Wysoki M., Bolland H.R. 1983 - Chromosome studies of phytoseiid mites (Acari: Gamasida) - Int. J. Acarol., 9 (2): 91-94. doi:10.1080/01647958308683319

Zchori-Fein E., Gottlieb Y., Kelly S.E., Brown J.K., Wilson J.M., Karr T.L., Hunter M.S. 2001 - A newly discovered bacterium associated with parthenogenesis and a change in host selection behavior in parasitoid wasps — PNAS, 98(22) 12555-12560.

Zug R., Hammerstein P. 2012 - Still a Host of Hosts for Wolbachia: analysis of recent data suggests that $40 \%$ of terrestrial arthropod species are infected - PloS one, 7(6): e38544. doi:10.1371/journal.pone.0038544

\section{COPYRIGHT}

$(\mathrm{cc})$ EY-No-ND Cavalcante A.C.C. et al. Acarologia is under free license. This open-access article is distributed under the terms of the Creative Commons-BY-NC-ND which permits unrestricted non-commercial use, distribution, and reproduction in any medium, provided the original author and source are credited. 